\title{
Extensive gunshot wound to the face: a case report
}

- Tales Gabriel de Souza Cerioni Medical-Surgical Anatomy Laboratory, School of Medicine, University of São Paulo (USP), São Paulo, SP, Brazil • Rafael Jorge Ruman Oral and Maxillofacial Surgery and Trauma Clinic Ruman, Osasco, SP, Brazil • Willian Jamil Hassanieh Oral and Maxillofacial Surgery and Trauma Clinic Ruman, Osasco, SP, Brazil • Gustavo Rodrigues Manrique Ideale Oral and Maxillofacial Surgery and Dental Implants, Osasco, SP, Brazil - Wladimir Gushiken de Campos Department of Stomatology, School of Dentistry, University of Sao Paulo (USP), São Paulo, SP, Brazil • Alexandre Viana Frascino Children's Hospital Sabará, São Paulo, SP, Brazil • Flavio Carneiro Hojaij Medical-Surgical Anatomy Laboratory, School of Medicine, University of Sao Paulo (USP), São Paulo, SP, Brazil

ABSTRACT | Facial fractures caused by gunshots are a major challenge for oral and maxillofacial surgeons. Underdeveloped countries present a higher rate of homicides committed by gunshots than developed countries. This case report presents a 25 year-old male victim of a gunshot wound to the mandible, evolving into a complex fracture. The fracture was treated using rigid internal fixation. After 18 months of follow-up, the patient presents good facial appearance and masticatory activity. The gunshot caused the permanent paralysis of the right mandibular branch of the facial nerve. We managed to preserve the involved teeth and mandibular integrity, with complete bone healing. Despite the late infection following plate fixation, healing occurred without further complications, indicating that blood supply was maintained.

DESCRIPTORS | Head Injuries, Penetrating; Gun Violence; Fracture Fixation, Internal; Jaw Fixation Techniques.

RESUMO | Ferimento Profundo no rosto causado por arma de fogo: relato de caso • As fraturas faciais causadas por arma de fogo são um grande desafio para o cirurgião oral e maxilofacial. Os países subdesenvolvidos apresentam uma taxa maior de homicídios cometidos por arma de fogo do que os países desenvolvidos. Este relato de caso apresenta um paciente do sexo masculino, 25 anos, vítima de ferimento por arma de fogo na mandíbula, evoluindo para fratura complexa. A fratura foi tratada com fixação interna rígida. Após 18 meses de seguimento, o paciente apresenta boa aparência facial e atividade mastigatória. O tiro causou paralisia permanente do ramo mandibular direito do nervo facial. Conseguimos preservar os dentes envolvidos e a integridade mandibular, com cicatrização óssea completa. Apesar da infecção tardia após a fixação da placa, a cicatrização ocorreu sem complicações adicionais, indicando que o suprimento de sangue foi mantido.

DESCRITORES | Traumatismos Cranianos Penetrantes; Violência com Arma de Fogo; Fixação Interna de Fraturas; Técnicas de Fixação da Arcada Osseodentária.

CORRESPONDING AUTHOR | • Wladimir Gushiken de Campos Department of Stomatology, School of Dentistry, University of Sao Paulo • Avenida Prof. Lineu Prestes, 2227 São Paulo, SP Brazil • 05508-000 E-mail: wgushiken@hotmail.com

- Received 24 Mar, 2021 • Accepted 19 Apr, 2021. 


\section{INTRODUCTION}

Facial trauma is a major public health issue with particularities in developing countries. The etiologies of facial trauma vary greatly, but gunshots are quite prevalent. This type of injury is associated with increased fracture and mortality rates. ${ }^{1}$

Homicide rates grew exponentially in Brazil during the last thirty years. Of all members of the World Health Organization (WHO), Brazil has the highest years of life lost to violence, and homicide victims in the country are more likely to be young, male, and black. ${ }^{2}$ Many homicides are committed by gunshots and in underdeveloped countries - where rates attributable to this crime are higher than in developed countries. ${ }^{3}$

Facial fractures caused by gunshots are a major challenge for oral and maxillofacial surgeons. Due to the various trauma patterns, hard-tissue injuries involving teeth, and the lack treatment standardization, treating these injuries is a quite complex tasks, possibly leading to a large number of trans and postoperative complications. ${ }^{4}$

This study aimed to report the case of a victim of a gunshot to the face.

\section{CASE REPORT}

In June 2019, a 25 year-old man was robbed while working as a motorcycle courier. Two bullets were fired straight to his face, but only one hit the target. On physical examination, the patient presented edema; ecchymosis; a floor-of-mouth hematoma; mandibular arch misalignment; fracture of the lower right mandible involving the mandibular first premolar, canine, lateral and central incisor; and gingival laceration (Figures $1 \mathrm{~A}$ and $\mathrm{B}$ ).

Computed tomography (CT) of the face showed a comminuted fracture in the mandibular body and mandibular symphysis at the right side, involving the mandibular first premolar, canine, lateral and central incisor, but with no other bone involvement (Figures 2A and B).

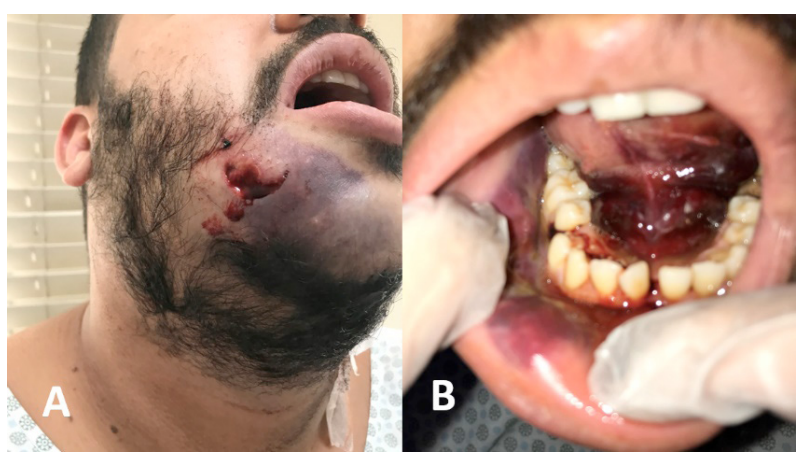

FIGURE 1 || A) Penetrating wound in the mandibular body, edema, and ecchymosis. B) Edema, ecchymosis, floor-of-mouth hematoma, mandibular arch misalignment, gingival laceration, and fracture of the lower right mandible involving the mandibular first premolar, canine, lateral, and central incisor.

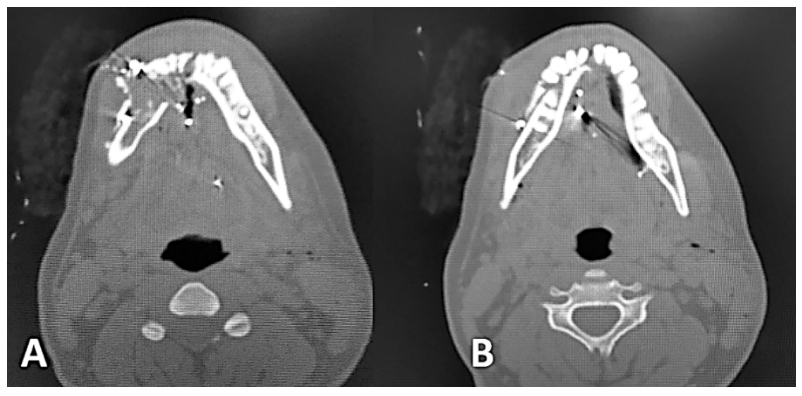

FIGURE 2 | A) CT of the face showing a comminuted fracture in the mandibular body and mandibular symphysis at the right side, involving the mandibular first premolar, canine, lateral, and central incisor. B) An upper tomographic section, showing the extent of the mandibular fracture.

Facial fracture was treated with open reduction and rigid internal fixation (RIF) via submandibular access under general anesthesia. Devitalized bone fragments were removed, the floor-of-mouth hematoma was drained, dentoalveolar fracture was stabilized, and the wound was sutured. No complications ensued during the operation and the patient was discharged from the hospital 24 hours after the procedure. Two months after surgical fixation, the patient underwent endodontic treatment for the involved tooth (Figures $3 \mathrm{~A}$ and B). 


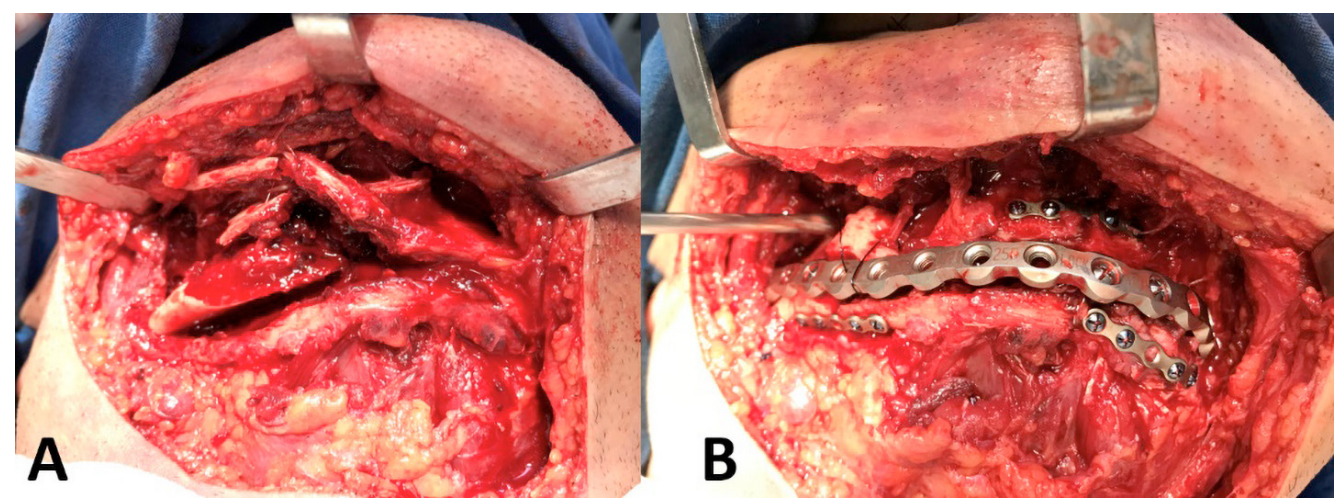

FIGURE 3 A) Macroscopic view of the comminuted fracture after extended submandibular access. B) Macroscopic view after reduction and rigid internal fixation with multiple plates.

In the sixth postoperative month, the patient returned with a surgical site infection and reported that a screw was externalized through a fistula in the submandibular access scar. The CT of the mandible indicated an area suggestive of osteolysis involving the osteosynthesis plate, so we performed fistulectomy and osteosynthesis plaque removal. The patient had no other complications until the final follow-up. In 18 postoperative months, CT indicated adequate bone repositioning and fixation stability (Figures $4 \mathrm{~A}$ and $\mathrm{B}$ ).

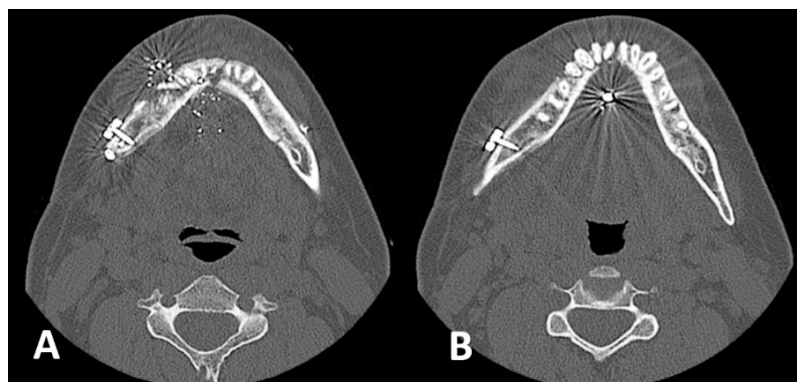

FIGURE 4 | A) 18-month postoperative CT of the face shows adequate bone repositioning and fixation stability. B) An upper tomographic section, showing adequate repositioning of teeth.

After 18 months of follow-up, the patient presents good facial appearance and masticatory activity. The gunshot caused the permanent paralysis of the right mandibular branch of the facial nerve. (Figures $5 \mathrm{~A}$ and $\mathrm{B}$ )

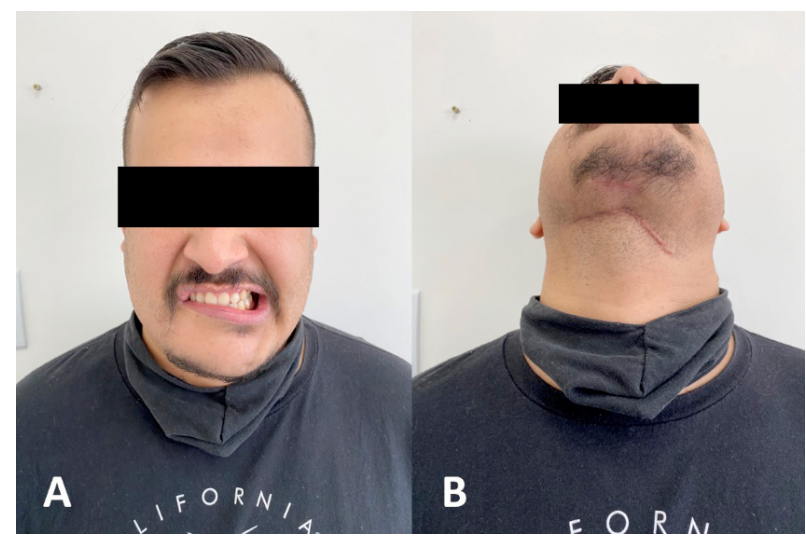

FIGURE 5 A) Permanent paralysis of the right mandibular branch of the facial nerve after 18 months of follow-up. B) Submandibular access scar without fistula after 18 months of follow-up.

\section{DISCUSSION}

Violence exerts an enormous pressure on social services and health and legal systems, besides being increasingly identified as a factor that damages economies due to its physical and emotional impacts on people. ${ }^{5}$ Five hundred million people were murdered in Brazil in 2010, most of whom were young men. ${ }^{2}$ This study reports the case of a 25 -yearold male victim and survivor of gun violence.

The severity of gunshot wounds is related to the shape, size, and kinetic energy of the projectile at the moment of impact, which in turn are associated with the distance traveled by the projectile. ${ }^{6}$ Although the victim of the reported case received 
two close-range shots, the mandible was the only facial tissue affected. A study conducted by Ambrosi et al.7 evaluated 110 victims of gunshots to the head, 27 of whom (24.5\%) died after surgical procedure due to the extension of injuries.

Victims of gunshot to the mandible must be primarily evaluated for neurological injuries, cervical spine trauma, and airway damage. Maintaining airway permeability is crucial in this type of trauma. After achieving airway stability, health professionals must assess tissue damage. ${ }^{4}$ Despite injuries, the patient of the case reported in this article breathed easily.

No consensus has been reached as to the best treatment for mandibular fractures due to gunshots. When analyzing the most effective treatment method for mandibular fractures due to gunshots, a recent systematic review ${ }^{4}$ found intermaxillary fixation (IMF) to be the most commonly used, followed by open surgery with rigid internal fixation (RIF) - the treatment method used in our patient. The authors concluded that patients treated with RIF are six times less likely to present with malunion than those treated with IMF. As in these cases bone healing is the main indicator of success in surgical treatment, this finding is truly relevant. In the case reported, we managed to preserve the involved teeth and the mandibular integrity, with complete bone healing.

Soft-tissue injuries also require special attention. Compromised blood supply may affect bone healing, cause infections, and lead to treatment failure. When evaluating 115 comminuted mandibular fractures, Rocha et al. ${ }^{4}$ found 19 of them to evolve with infections: 13 related to RIF; three to external fixators; and three to IMF. To visualize bone fragments involved in the fracture, patients underwent extraoral incisional biopsy. In our patient, despite the late infection following plate fixation, healing occurred without complications, indicating that blood supply was maintained.

\section{CONCLUSIONS}

The treatment used for the mandibular fracture due to gunshot enabled us to preserve the involved teeth and the mandibular integrity of the victim.

\section{REFERENCES}

1. Ribeiro ALR, Gillet LCS, Vasconcelos HG, Rodrigues LC, Pinheiro JJV, Alves-Junior SM. Facial Fractures: Large Epidemiologic Survey in Northern Brazil Reveals Some Unique Characteristics. J. Oral Maxillofac Surg. 2016;74(12):2480. e1-2480.e12. doi: 10.1016/j.joms.2016.08.015.

2. Murray J, Cerqueira DRC, Kahn T. Crime and violence in Brazil: Systematic review of time trends, prevalence rates and risk factors. Aggress Violent Behav. 2013;18(5):471-83. doi: 10.1016/j.avb.2013.07.003.

3. Van Den Bergh B, Karagozoglu KH, Heymans MW, Forouzanfar T. Aetiology and incidence of maxillofacial trauma in Amsterdam: A retrospective analysis of 579 patients. J CranioMaxillofac Surg. 2012;40(6):e165-e169. doi: 10.1016/j. jcms.2011.08.006.

4. Rocha SS, Sales PHH, Carvalho PHR, Maia RN, Gondim RF, Menezes JMS Jr, et al. Mandibular traumas by gunshot. A systematic review with meta-analysis and algorithm of treatment. Br J Oral Maxillofac Surg. 2021;59(3):e99-e108. doi: 10.1016/j.bjoms.2020.08.019.

5. Malta DC, Minayo MCS, Soares Filho AM, Silva MMA, Montenegro MMS, Ladeira RM, et al. Mortalidade e anos de vida perdidos por violências interpessoais e autoprovocadas no Brasil e Estados: Análise das estimativas do Estudo Carga Global de Doença, 1990 e 2015. Rev Bras Epidemiol. 2017;20(Suppl 1):142-56. doi: 10.1590/1980-5497201700050012.

6. Peled M, Leiser Y, Emodi O, Krausz A. Treatment Protocol for High Velocity/High Energy Gunshot Injuries to the Face. Craniomaxillofac Trauma Reconstr. 2012;5(1):31-40. doi: 10.1055/s-0031-1293518.

7. Ambrosi PB, Valença MM, Azevedo Filho H. Prognostic factors in civilian gunshot wounds to the head: A series of 110 surgical patients and brief literature review. Neurosurg Rev. 2012;35(3):429-35. doi: 10.1007/s10143-012-0377-2. 